\title{
Toxinotyping and antimicrobial resistance of Clostridium perfringens isolated from processed chicken meat products
}

\author{
Dalia Hamza ${ }^{1}$, Sohad Dorgham ${ }^{2}$, Ashraf Hakim² \\ ${ }^{1}$ Department of Zoonoses, Faculty of Veterinary Medicine, Cairo University, Giza 11221, Egypt \\ ${ }^{2}$ Department of Microbiology and Immunology, National Research Centre, Giza 12622, Egypt \\ daliahamza@cu.edu.eg
}

Received: September 26, $2016 \quad$ Accepted: March 8, 2017

\begin{abstract}
Introduction: The toxinotyping and antimicrobial susceptibility of Clostridium perfringens strains isolated from processed chicken meat were determined. Material and Methods: Two hundred processed chicken meat samples from luncheon meats, nuggets, burgers, and sausages were screened for Clostridium perfringens by multiplex PCR assay for the presence of alpha (cpa), beta (cpb), epsilon (etx), iota (ia), and enterotoxin toxin (cpe) genes. The C. perfringens isolates were examined in vitro against eight antibiotics (streptomycin, amoxicillin, ampicillin, ciprofloxacin, lincomycin, cefotaxime, rifampicin, and trimethoprimsulfamethoxazole) Results: An overall of 32 C. perfringens strains (16\%) were isolated from 200 processed chicken meat samples tested. The prevalence of $C$. perfringens was significantly dependent on the type of toxin genes detected $(\mathrm{P}=0.0)$, being the highest in sausages $(32 \%)$, followed by luncheon meats $(24 \%)$, burgers $(6 \%)$, and nuggets $(2 \%)$. C. perfringens type A was the most frequently present toxinotype (24/32; 75\%), followed by type $\mathrm{D}(21.9 \%)$ and type $\mathrm{E}(3.1 \%)$. Of the 32 C. perfringens strains tested, only $9(28 \%)$ were enterotoxin gene carriers, with most representing type A $(\mathrm{n}=6)$. C. perfringens strains differed in their resistance/susceptibility to commonly used antibiotics. Most of the strains tested were sensitive to ampicillin (97\%) and amoxicillin (94\%), with $100 \%$ of the strains being resistant to streptomycin and lincomycin. It is noteworthy that the nine isolates with enterotoxigenic potential had a higher resistance than the non-enterotoxigenic ones. Conclusion: The considerably high C. perfringens isolation rates from processed chicken meat samples and resistance to some of the commonly used antibiotics indicate a potential public health risk. Recent information about the isolation of enterotoxigenic C. perfringens type $\mathrm{E}$ from chicken sausage has been reported.
\end{abstract}

Keywords: processed chicken meat, Clostridium perfringens, enterotoxin, antimicrobial resistance.

\section{Introduction}

The microbiological quality and safety of meat are significant for the health of consumers around the world (25). Anaerobic bacteria constitute an important group of microorganisms that are responsible for many public health hazards. C. perfringens is a member of this group that is more widely spread than others, since its principal habitats are the soil and intestinal contents of humans and animals (18). Disease flare-up due to $C$. perfringens can have various origins, one of which is poultry (15).

In poultry, $C$. perfringens constitutes a human health hazard through the food chain and is one of the most frequently isolated bacterial pathogens from chicken meat, constituting up to $70 \%-98 \%$ of the cases $(7,9)$. C. perfringens is an omnipresent pathogen of the intestinal tract of poultry, associated with different phases of poultry growth and production. Chicken carcasses and meat parts may likewise be contaminated with $C$. perfringens during evisceration in the slaughterhouse (29).

$C$. perfringens causes a number of human diseases ranging from necrotic enteritis to wound infection and life-threatening gas gangrene (21). C. perfringens has been grouped into five types (A-E) based on toxins produced (alpha, beta, epsilon, and iota). The alpha toxin is produced by all the types of Clostridium perfringens. The toxin is a necrotising toxin which is believed to be a virulence marker $(4,22)$. In addition, $C$. perfringens produces other minor toxins, such as enterotoxins, which are not associated with a specific strain and are responsible for causing the gastrointestinal disorders that may be food- or non-food-borne. 
The enterotoxin gene (cpe) exists on either a chromosome in food-poisoning isolates or a large conjugative plasmid in non-food-borne gastrointestinal disease (12).

Our study aimed to detect the presence of C. perfringens in processed chicken meat samples (luncheon, nuggets, burger, and sausage) and characterise the isolates for the existence of enterotoxin gene. In addition, the in vitro resistance of $C$. perfringens isolates against certain antibiotics was determined.

\section{Material and Methods}

Samples. In total, 200 processed chicken meat samples of luncheon, nuggets, burger, and sausage $(n=50$ each) were collected from different markets in Cairo during the period from March to April 2015. When collected, the samples were directly transferred in iceboxes to the laboratory.

C. perfringens isolation and identification. Ten grams of each sample was diluted in $90 \mathrm{~mL}$ of sterile $0.1 \%$ peptone water and homogenised in a blender at $2000 \mathrm{rpm}$ for 1-2 min. About $1 \mathrm{~mL}$ of each homogenised food suspension was inoculated into cooked meat broth tubes and incubated anaerobically at $37^{\circ} \mathrm{C}$ for $48 \mathrm{~h}$. A loopful form each tube was streaked on neomycin sulphate sheep blood agar plates and incubated anaerobically for a further $48 \mathrm{~h}$. Suspected colonies were examined microscopically and biochemically (9).

DNA extraction and PCR assay. DNA was extracted from pure colonies of $C$. perfringens that showed a double zone of haemolysis on blood agar by using an extraction kit (QIA amp Mini Kit, Qiagen, Germany). Specific oligonucleotide primers for the alpha (cpa), beta (cpb), epsilon (etx), iota (ia), and enterotoxin toxin (cpe) genes of $C$. perfringens were used as described in Table 1 . Multiplex PCR assay was carried out in a reaction mixture $(25 \mu \mathrm{L})$ containing $1 \mu \mathrm{L}$ of template DNA, $12.5 \mu \mathrm{L}$ of Dream Taq Green PCR Master mix, $0.5 \mu \mathrm{L}$ of each primer $(10 \mathrm{pmol} / \mu \mathrm{L})$, and $10.5 \mu \mathrm{L}$ of DNase-free water. PCR amplification was carried out in a Biometra PCR thermal cycler. Following initial denaturation for $3 \mathrm{~min}$ at $94^{\circ} \mathrm{C}$, the samples were subjected to 35 cycles of denaturation at $94^{\circ} \mathrm{C}$ for $1 \mathrm{~min}$, annealing at $55^{\circ} \mathrm{C}$ for $1 \mathrm{~min}$, extension at $72^{\circ} \mathrm{C}$ for $1 \mathrm{~min}$, and final extension for $10 \mathrm{~min}$ at $72^{\circ} \mathrm{C} \mathrm{(28).} \mathrm{The}$ PCR reaction mixtures were analysed by electrophoresis using $1.5 \%(\mathrm{w} / \mathrm{v})$ agarose gel in the presence of $100 \mathrm{bp}$ DNA ladder (Fermentas Life Science, EU) (14). Types D and $\mathrm{E}$, and positive-control of national $C$. perfringens strains were also included in the PCR.

Antimicrobial sensitivity test. Thirty-two C. perfringens isolates were examined in vitro against eight antibiotics, which included streptomycin (10 $\mu \mathrm{g})$, amoxicillin $(10 \mu \mathrm{g})$, ampicillin $(10 \mu \mathrm{g})$, ciprofloxacin $(5 \mu \mathrm{g})$, lincomycin $(30 \mu \mathrm{g})$, cefotaxime $(30 \mu \mathrm{g})$, rifampicin $(5 \mu \mathrm{g})$, and trimethoprim-sulfamethoxazole $(1.25+23.75 \mu \mathrm{g})$ (Oxoid, UK). The test was carried out using the agar disc diffusion test, $(17,26)$. The isolates were cultured anaerobically at $37^{\circ}$ for $24 \mathrm{~h}$ in $10 \%$ neomycin sheep blood agar, then suspended in $0.9 \% \mathrm{NaCl}$ to a $0.5 \mathrm{McF}$ arland standard. Every isolate was inoculated onto MuellerHinton agar plates (Remel, USA) and the antibiotic discs were applied. The plates were incubated anaerobically at $37^{\circ}$ for $24 \mathrm{~h}$. The interpretation of the results was performed according to CLSI, 2012 (8).

Statistical analysis. PASW Statistics, Version 18.0. software (SPSS Inc., USA) was used to analyse the data. The Chi square $\left(\mathrm{x}^{2}\right)$ test was applied (provided that at least $80 \%$ of the cells had an expected frequency of five or greater, and that no cell had an expected frequency smaller than 1.0). Otherwise, the Fisher-Freeman-Halton Exact test was used (i.e. the Fisher's Exact test for contingency tables larger than $2 \times 2$ ). A value of $\mathrm{P}<5$ was considered as significant.

\section{Results}

Overall, 32 C. perfringens isolates were obtained from 200 processed chicken meat samples (luncheon, nuggets, burger, and sausage; 50 of each with an incidence of $16 \%$, Table 2). There was a relationship between the kind of meat and the occurrence of $C$. perfrigens. A high isolation rate was observed in sausage samples (16/50), followed by luncheon $(12 / 50)$, while nuggets showed the lowest rate $(1 / 50)$. The results in Table 2 show that the rate of C. perfringens type A was high (24/32), followed by that of type $\mathrm{D}(7 / 32)$, and then the unprecedented isolation of type E in sausage (1/32).

Fig. 1A shows the amplification of alpha toxin gene at $324 \mathrm{bp}$, representing $C$. perfringens type $\mathrm{A}$, while amplifications of epsilon toxin gene at $655 \mathrm{bp}$ and alpha toxin gene represented $C$. perfringens type D. In addition, Fig. 1A shows the presence of enterotoxigenic C. perfringens gene (cpe) at $233 \mathrm{bp}$. In Fig. 1B, type C was used as a positive control revealing two bands, one at 324 bp for the alpha gene and another at $196 \mathrm{bp}$ for the beta gene. Fig. 1B also shows the amplification of iota toxin gene at $446 \mathrm{bp}$ and alpha toxin gene representing the isolated $C$. perfringens type $\mathrm{E}$. The cpe gene was represented in Fig. 1 by amplification at $233 \mathrm{bp}$ for enterotoxigenic $C$. perfringens type A (Fig. 1A) and C. perfringens enterotoxin type E (Fig. 1B). According to Table 3, the enterotoxigenic isolates which carried cpe gene amounted to 9 out of $32 C$. perfringens isolates with an incidence of $28 \%$. Enterotoxigenic $C$. perfringens type A was most frequently isolated (6/24), followed by type D $(2 / 7)$, and then type $\mathrm{E}(1 / 1)$.

Antibiotic sensitivity test. The occurrence of antibiotic resistance among $32 \mathrm{C}$. perfringens isolates was as follows: streptomycin (100\%), lincomycin (100\%), trimethoprim-sulfamethoxazole $(94 \%)$, ciprofloxacin $(41 \%)$, cefotaxime $(34 \%)$, and rifampicin $(31 \%)$. On the other hand, the isolates showed high sensitivity to amoxicillin (94\%) and ampicillin (97\%). Out of 32 $C$. perfringens isolates, the nine that harboured the enterotoxin gene, demonstrated a higher resistance to the antibiotics compared to non-enterotoxigenic isolates (Table 4). 
Table 1. Multiplex PCR primers for five toxins genes of C. perfringens

\begin{tabular}{llcc}
\hline Gene & \multicolumn{1}{c}{ Primer Sequence } & $\begin{array}{c}\text { Amplified } \\
\text { size (bp) }\end{array}$ & Reference \\
\cline { 1 - 3 }$c p a$ & $\begin{array}{l}\text { GCTAATGTTACTGCCGTTGA } \\
\text { CCTCTGATACATCGTGTAAG }\end{array}$ & \multirow{2}{*}{324} & \\
\cline { 1 - 2 }$c p b$ & $\begin{array}{l}\text { GCGAATATGCTGAATCATCTA } \\
\text { GCAGGAACATTAGTATATCTTC }\end{array}$ & \multirow{2}{*}{196} \\
\cline { 1 - 3 }$e t x$ & $\begin{array}{l}\text { GCGGTGATATCCATCTATTC } \\
\text { CCACTTACTTGTCCTACTAAC }\end{array}$ & \multirow{2}{*}{655} \\
\cline { 1 - 2 }$i a$ & $\begin{array}{l}\text { ACTACTCTCAGACAAGACAG } \\
\text { CTTTCCTTCTATTACTATACG }\end{array}$ & \multirow{2}{*}{446} \\
\cline { 1 - 2 }$c p e$ & $\begin{array}{l}\text { ACTACTCTCAGACAAGACAG } \\
\text { CTTTCCTTCTATTACTATACG }\end{array}$ & 233 \\
\hline
\end{tabular}

Table 2. Occurrence of $C$. perfringens among examined samples and typing of $C$. perfringens isolates by using multiplex PCR

\begin{tabular}{|c|c|c|c|c|c|c|c|c|c|c|}
\hline \multirow{3}{*}{ Sample } & \multirow{3}{*}{$\begin{array}{c}\text { Number } \\
\text { of } \\
\text { samples }\end{array}$} & & & \multicolumn{6}{|c|}{ C. perfringens type } & \multirow{3}{*}{ P-value } \\
\hline & & \multicolumn{2}{|c|}{ Positive samples } & \multicolumn{2}{|c|}{ A } & \multicolumn{2}{|c|}{$\mathrm{D}$} & \multicolumn{2}{|c|}{ E } & \\
\hline & & Number & $\%$ & Number & $\%$ & Number & $\%$ & Number & $\%$ & \\
\hline Luncheon & 50 & 12 & 24 & 9 & 75 & 3 & 25 & 0 & 0 & $0.0 *$ \\
\hline Nuggets & 50 & 1 & 2 & 1 & 100 & 0 & 0 & 0 & 0 & 1.0 \\
\hline Burger & 50 & 3 & 6 & 3 & 100 & 0 & 0 & 0 & 0 & 0.035 * \\
\hline Sausage & 50 & 16 & 32 & 11 & 69 & 4 & 25 & 1 & 6 & $0.0 *$ \\
\hline Total & 200 & 32 & 16 & 24 & 75 & 7 & 21.9 & 1 & $3.1 \%$ & $0.0 *$ \\
\hline P-value & & \multicolumn{2}{|c|}{$0.000 *$} & \multicolumn{2}{|c|}{0.885} & \multicolumn{2}{|c|}{0.999} & \multicolumn{2}{|c|}{1.000} & \\
\hline
\end{tabular}

* a significant difference

Table 3. Occurrence of $C$. perfringens enterotoxin in different toxin types

\begin{tabular}{|c|c|c|c|c|c|c|}
\hline \multirow{3}{*}{ Sample } & \multicolumn{6}{|c|}{ C. perfringens enterotoxin type } \\
\hline & \multicolumn{2}{|c|}{ A } & \multicolumn{2}{|c|}{$\mathrm{D}$} & \multicolumn{2}{|c|}{$\mathrm{E}$} \\
\hline & Number & $\%$ & Number & $\%$ & Number & $\%$ \\
\hline Luncheon & $2(9)$ & 22 & $1(3)$ & 33 & $0(0)$ & 0 \\
\hline Nuggets & $0(1)$ & 0 & $0(0)$ & 0 & $0(0)$ & 0 \\
\hline Burger & $1(3)$ & 33 & $0(0)$ & 0 & $0(0)$ & 0 \\
\hline Sausage & $3(11)$ & 27 & $1(4)$ & 25 & $1(1)$ & 100 \\
\hline Total & 6 & 25 & 2 & 28 & 1 & 100 \\
\hline \multirow[t]{2}{*}{ P-value } & \multicolumn{2}{|c|}{0.999} & \multicolumn{2}{|c|}{0.999} & \multicolumn{2}{|c|}{1.000} \\
\hline & \multicolumn{6}{|c|}{9 out of $32(28 \%)$} \\
\hline
\end{tabular}

Table 4. Antibiogram of Clostridium perfringens strains isolated from processed chicken meat products

\begin{tabular}{|c|c|c|c|c|c|c|c|c|c|c|c|c|}
\hline \multirow{4}{*}{ Antimicrobials } & \multicolumn{12}{|c|}{ Antibiotic profile } \\
\hline & \multicolumn{6}{|c|}{ Resistant } & \multicolumn{6}{|c|}{ Sensitive } \\
\hline & \multicolumn{2}{|c|}{$\begin{array}{c}{ }^{* a} \mathrm{CPE}^{+} \\
(9) \\
\end{array}$} & \multicolumn{2}{|c|}{$\begin{array}{c}\text { *b }^{* \mathrm{CPE}}- \\
(23)\end{array}$} & \multicolumn{2}{|c|}{$\begin{array}{c}\text { Total } \\
(32) \\
\end{array}$} & \multicolumn{2}{|c|}{$\begin{array}{c}\mathrm{CPE}^{+} \\
(9) \\
\end{array}$} & \multicolumn{2}{|c|}{$\begin{array}{c}\mathrm{CPE}^{-} \\
(23) \\
\end{array}$} & \multicolumn{2}{|c|}{$\begin{array}{c}\text { Total } \\
(32) \\
\end{array}$} \\
\hline & No. & $\%$ & No. & $\%$ & No. & $\%$ & No. & $\%$ & No. & $\%$ & No. & $\%$ \\
\hline Streptomycin & 9 & 100 & 23 & 100 & 32 & 100 & 0 & 0 & 0 & 0 & 0 & 0 \\
\hline Lincomycin & 9 & 100 & 23 & 100 & 32 & 100 & 0 & 0 & 0 & 0 & 0 & 0 \\
\hline $\begin{array}{l}\text { Trimethoprim- } \\
\text { sulfamethoxazole }\end{array}$ & 9 & 100 & 21 & 91 & 30 & 94 & 0 & 0 & 2 & 9 & 2 & 6 \\
\hline Ciprofloxacin & 6 & 67 & 7 & 30 & 13 & 41 & 3 & 33 & 16 & 70 & 19 & 59 \\
\hline Cefotaxime & 4 & 44 & 7 & 30 & 11 & 34 & 5 & 56 & 16 & 70 & 21 & 66 \\
\hline Rifampicin & 5 & 56 & 5 & 22 & 10 & 31 & 4 & 44 & 18 & 78 & 22 & 69 \\
\hline Amoxicillin & 1 & 11 & 1 & 4 & 2 & 6 & 8 & 89 & 22 & 96 & 30 & 94 \\
\hline Ampicillin & 1 & 11 & 0 & 0 & 1 & 3 & 8 & 89 & 23 & 100 & 31 & 97 \\
\hline
\end{tabular}

${ }^{* a} \mathrm{CPE}^{+}-C$. perfringens enterotoxin positive; ${ }^{* \mathrm{~b}} \mathrm{CPE}^{-}-C$. perfringens enterotoxin negative 

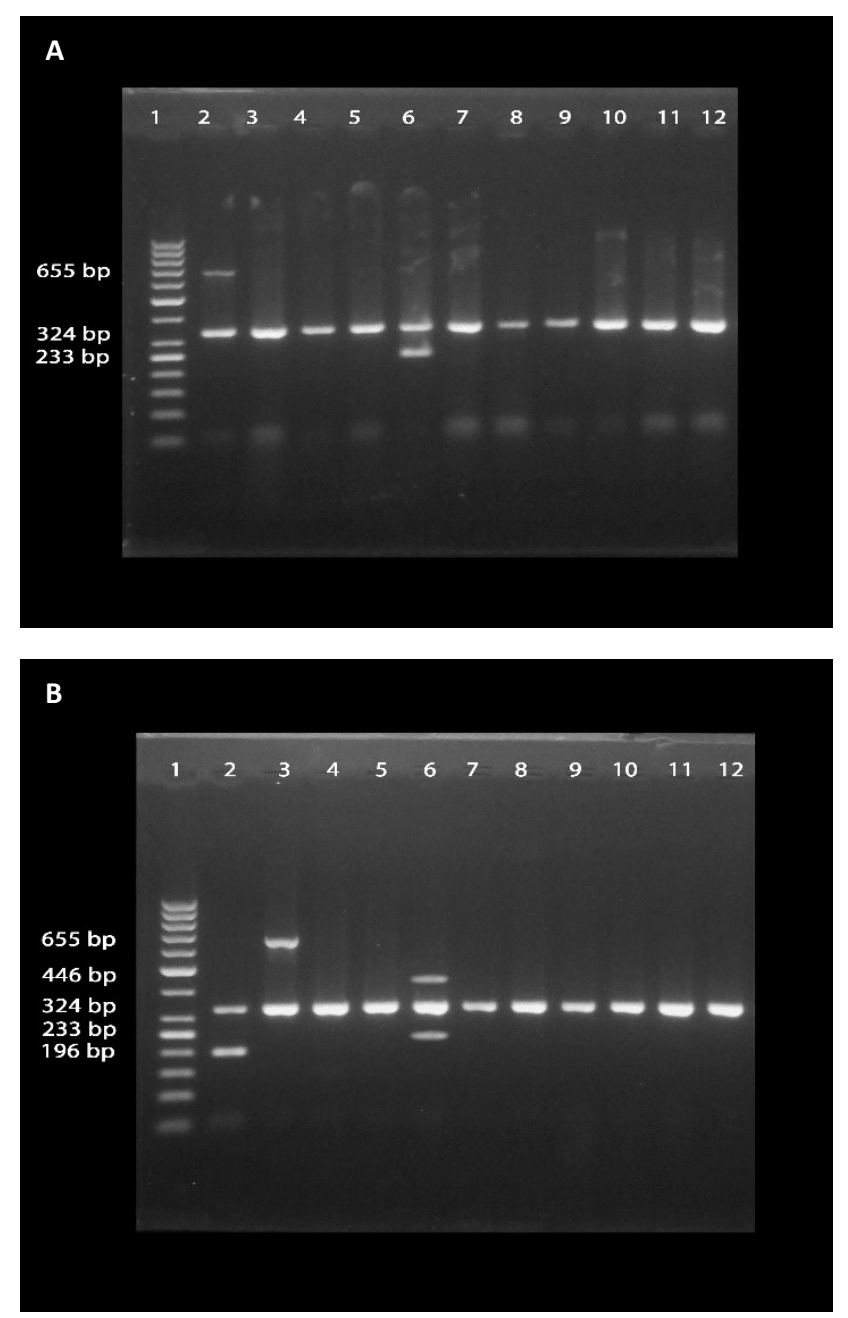

Fig. 1. Agarose gel electrophoresis of multiplex PCR products of C. perfringens strains isolated from selected chicken meat products and a positive control

A) Lane $1-50 \mathrm{bp}$ DNA ladder. Lane $2-C$. perfringens type D (positive control). Lane $6-C$. perfringens type A, enterotoxin. Lanes $3,4,5$, and 7 to $12-C$. perfringens type $\mathrm{A}$

B) Lane 1-50bp DNA ladder. Lane 2-C.perfringens type C (positive control). Lane $3-C$. perfringens type D. Lane 6 C. perfringens type E, enterotoxin. Lanes 4,5 , and 7 to 12 C. perfringens type $\mathrm{A}$

\section{Discussion}

Food can be a source of different human ailments, therefore identification and control of food pathogens are a fundamental part of nourishment microbiology. C. perfringens was responsible for food poisoning in the 1940s; ever since, cases of food poisoning due to C. perfringens contamination have been reported (6).

According to our results, $C$. perfringens was isolated in $16 \%$ of 200 processed chicken meat samples collected from the Egyptian markets. This result is similar to that of Nasr et al. (23) who reported an isolation rate of $14.3 \%$, while in another study, a high $37 \%$ prevalence was noted (20). In our study, the occurrence of $C$. perfringens may be possibly attributed to the method adapted in preparing chicken meat products. Moreover, the occurrence of $C$. perfringens may be ascribed to a high protein content in sampled products (13)

As shown in Table 2 and Figs $1 \mathrm{~A}$ and 1B, C. perfringens type A was the most predominant type among $C$. perfringens isolates. The percentages of isolation of that type from luncheon, nuggets, burger, and sausage were $75,100,100$, and 69 , respectively. $C$. perfringens type D was isolated in $25 \%, 0 \%, 0 \%$, and $25 \%$ of the cases, respectively. $C$. perfringens type E was only isolated from sausage samples, constituting $6 \%$ of isolates. These results are in accordance with results of Nasr et al. (23) who found that $70.8 \%$ of toxigenic isolates from processed chicken meat products proved to be $C$. perfringens type A, while $12.9 \%$ of the isolates belonged to type $\mathrm{D}$.

A small percentage of $C$. perfringens produces the enterotoxin (CPE), which is responsible for food poisoning. CPE has been also associated with sporadic diarrhoea and in some cases with sudden infant death syndrome (5).

Table 3 shows that out of $32 C$. perfringens strains, six of enterotoxigenic strains belonged to type A, two to type $\mathrm{D}$, and one to type $\mathrm{E}$. This is similar to observations of Khan et al. (16) who toxinotyped six C. perfringens isolates from raw chicken meat and found that three of them were of type A and one each of the remaining three belonged to types $\mathrm{B}, \mathrm{C}$, and $\mathrm{D}$. Likewise, the recognition of enterotoxin genes in type A isolates collected from raw and processed chicken meat products was reported by Guran and Oksuztepe (13). Moreover, the prevalence of $C$. perfringens exotoxin and enterotoxin was not related to the type of product $(\mathrm{P}>0.05)$ (Tables 2 and $3)$. In fact, $C$. perfringens type A was isolated in almost all studies in which poultry meat was examined (24). Additionally, cpe gene was identified in C. perfringens isolates of all types (A-E), but type A was unusually common (18).

Interestingly, our results (Fig. 1B) provided some novel information about the isolation of $C$. perfringens enterotoxin type $\mathrm{E}$ from chicken sausage. This observation may account for several foodborne C. perfringens outbreaks that could be linked mainly to chromosomal cpe type A strains with heat-resistant spores, or occasionally less heat-resistant spore-forming plasmid cpe type A strains; both can be found in retail foods (21).

Furthermore, we examined the occurrence of resistance of $32 \mathrm{C}$. perfringens isolates to eight antibiotics which are widely used in poultry farms (Table 4). It was found that antibiotic sensitivity was highly related to the type of antibiotic used, either in $C$. perfringens enterotoxin-positive or -negative strains. The resistance to streptomycin, lincomycin, and trimethoprim-sulfamethoxazole was $100 \%, 100 \%$, and 94\% respectively, while appropriate percentages for ciprofloxacin, cefotaxime, and rifampicin were 41, 34, and 31, respectively. On the other hand, C. perfringens isolates showed high sensitivity to amoxicillin (94\%) and ampicillin (97\%). 
These results are in agreement with those of Osman and Elhariri (26) who mentioned that $C$. perfringens isolates showed high resistance to streptomycin (100\%), lincomycin $(100 \%)$, and trimethoprim-sulfamethoxazole $(98 \%)$. Furthermore, previously reported results $(27,2)$ showed intermediate sensitivity of $C$.perfringens to cefotaxime, ciprofloxacin, and low sensitivity to lincomycin. Abd-El Gwad and Abd El-Kader (1) demonstrated that $C$. perfringens isolates were highly sensitive to ampicillin, ciprofloxacin, and amoxicillin, which is consistent with our results suggesting that ampicillin and amoxicillin may be the drugs of choice for C. perfringens infection (3). Moreover, we found that $C$. perfringens isolates which carried enterotoxin gene showed a higher resistance to the antibiotics than nonenterotoxigenic isolates.

The frequent isolation of $C$. perfringens from processed chicken meat makes a public health risk. Its prevalence may be due to unhygienic measures not only during chicken rearing, but also during industrial processing. C. perfringens in poultry seems to occur very early and can be transmitted within the broiler chicken production, starting from the hatchery (10). Notably, C. perfringens is found in eggshell cracks, chicken fluff, and paper pads present in the hatchery (11).

Our study affirmed that there is a noticeable increase in the occurrence of enterotoxigenic $C$. perfringens in processed chicken meat, especially sausage. Moreover, we identificated $C$. perfringens enterotoxin type $\mathrm{E}$ in chicken meat. The study also contends that enterotoxigenic isolates of $C$. perfringens are more resistant to antibiotics than nonenterotoxigenic isolates.

Conflict of Interests Statement: The authors declare that there is no conflict of interests regarding the publication of this article.

Financial Disclosure Statement: This work was not funded by any organisation.

Animal Rights Statement: None required.

Acknowledgements: We would like to express our deepest thanks to Dr. Elshaimaa Ismael, Faculty of Veterinary Medicine, Cairo University, Egypt, for her kind help in statistical analysis.

\section{References}

1. Abd-El Gwad A.M., Abd El-Kader H.A.: The occurrence of Clostridium perfringens in the intestine of broiler chickens Assiut governorate. Ass Univ Bull Environ Res 2001, 4, 13-22.

2. Abd El-Hamid H.S., Ellakany H.F., Aboelmagd B.A., Elbestawy A.R., Bedawy Sh.: Clinical and laboratory studies on chicken isolates of Clostridium perfringens in El-Behera, Egypt. J World's Poult Res 2015, 5, 21-28.

3. Agunos A., Léger D., Carson C.: Review of antimicrobial therapy of selected bacterial diseases in broiler chickens in Canada. Can Vet J 2012, 53, 1289-300.
4. Ata N., Khairy E.A., Dorgham S.M., Zaki M.S.: Clostridium perfringens disease. Life Sci J 2013, 10, 1599-1602.

5. Bos J., Smithee L., McClane B., Distefano R.F., Uzal F.: Fatal necrotizing colitis following a foodborne outbreak of enterotoxigenic Clostridium perfringens type A infection. Clin Infect Dis 2005, 40, 78-83.

6. Brynestad S., Granum P.E.: Clostridium perfringens and foodborne infections. Int J Food Microbiol 2002, 74, 195-202.

7. Cakmak O., Ormanc F.S.D., Tayfur M., Erol I.: Presence and contamination level of Clostridium perfringens in raw frozen ground poultry and poultry burgers. Turk J Vet Anim Sci 2006, 30, 101-105.

8. CLSI: Performance standards for antimicrobial susceptibility testing, Twenty-Fourth Informational supplement. 2012, M100 S24. Villanova, USA.

9. Collee J.G., Fraser A.G., Marmion B.P., Simmons A.: Practical medical microbiology. $14^{\text {th }}$ education, Churchill Living Stone, New York 1996.

10. Craven S.E., Cox N.A., Bailey J.S., Cosby D.E.: Incidence and tracking of Clostridium perfringens through an integrated broiler chicken operation. Avian Dis 2003, 47, 707-711.

11. Craven S.E., Cox N.A., Stern N.J., Mauldin J.M.: Prevalence of Clostridium perfringens in commercial broiler hatcheries. Avian Dis 2001, 45, 1050-1053.

12. Freedman C.J., Archana S., Bruce A., McClane B.A.: Clostridium perfringens enterotoxin: action, genetics, and translational applications. Toxins 2016, 8, 73.

13. Guran H.S., Oksuztepe G.: Detection and typing of Clostridium perfringens from retail chicken meat parts. Lett Appl Microbiol 2013, 57, 77-82.

14. Hamza D.A., Ghoneim N.H.: Epidemiological studies on Clostridium perfringens food poisoning, Scholar press. Omniscriptum Marketing DEU, Germany 2015.

15. Hook D., Jalaludin B., Fitzsimmons G.: Clostridium perfringens food-borne-outbreak: an epidemiological investigation. Aust NZ J Public Health 1996, 20, 119-122.

16. Khan M., Nazir J., Anjum A.A., Ahmad M.U., Nawaz M.: Toxinotyping and antimicrobial susceptibility of enterotoxigenic Clostridium perfringens isolates from mutton, beef and chicken meat. J Food Sci Technol 2015, 52, 5323-5328.

17. Martel A., Devriese L.A., Cauwerts K., De-Gussem K., Decostere A.: Susceptibility of Clostridium perfringens isolates from broiler chickens to antibiotics and anti-coccidials. Avian Pathol 2004, 31, 3-7.

18. McClane B.A.: Clostridium perfringens, In: Food Microbiology, edited by Doyle M.P., Beuchat L.R., ASM press, Washington 2007, pp. 423-444.

19. Miki Y., Miyamoto K., Kaneko-Hirano I., Fujiuchi K., Akimoto S.: Prevalence and characterization of enterotoxin gene carrying Clostridium perfringens from retail meat products in Japan. Appl Environ Microbiol 2008, 74, 5366-5372.

20. Miwa N., Nishina T., Kubo S., Atsumi M, Honda H.: Amount of enterotoxigenic Clostridium perfringens in meat detected by nested PCR. Int J Food Microbiol 1998, 42, 195-200.

21. Miyamoto K., Li J., McClane B.A.: Enterotoxigenic Clostridium perfringens: detection and identification. Microbes Environ 2012, 27, 343-349.

22. Murray P.R., Baron E.J.O., Pfaller M.A.J., Orgensen J.H., Yolken R.H.: Clostridium, Manual of Clinical Microbiology, Vol. 1, ASM Press, Washington 2003, pp. 940-966.

23. Nasr E.M., Shehta A.A., Amer A.H.: Enterotoxigenicity and typing of Clostridium perfringens isolates from some poultry products in Egypt. J Appl Sci Res 2007, 3, 1804-1808.

24. Nowell V.J., Poppe C., Parreira V.R., Jiang Y.F., Reid-Smith R.: Clostridium perfringens in retail chicken. Anaerobe 2010, 16, 314-315.

25. Okolocha E.C., Ellerbroek L.: The influence of acid and alkaline treatments on pathogens and the shelf life of poultry meat. Food Control 2005, 16, 217-225 
26. Osman K.M., Elhariri M.: Antibiotic resistance of Clostridium perfringens isolates from broiler chickens in Egypt. Rev Sci Tech Off Int Epiz 2013, 32, 841-850.

27. Silva R.O.S., Francisco C.F.J., Marcus V.R.M., Carlos A.O.J., Nelson R.M.: Genotyping and antimicrobial susceptibility of Clostridium perfringens isolated from Tinamidae, Cracidae and Ramphastidae species. Brazil Cienc Rural 2014, 44, 486-491.
28. van Asten A.J., van der Wiel C.W., Nikolaou G., Houwers D.J., Grone A.A.: Multiplex PCR for toxin typing of $C$. perfringens. Vet Microbiol 2009, 136, 411-412.

29. Voidarou C., Vassos D., Rozos G., Alexopoulos A., Plessas A.: Microbial challenges of poultry meat production. Anaerobe 2011, $17,341-343$. 